\title{
IQTISHODUNA
}

IQTISHODUNA: Jurnal Ekonomi Islam

E-ISSN: 2443-0056, P-ISSN: 2252-5661

Accredited Sinta 2 Number 148/M/KPT/2020

Volume 10 Issue 1, April 2021 | Page: 035-044

DOI: $\underline{\text { doi.org/10.36835/iqtishoduna.v10i1.902 }}$

\section{The Strategy of Trade In The Halal Food Industry In Jember}

\author{
Misbahul Munir ${ }^{*}$, Muhammad Masyhuri² \\ ${ }^{1}$ Departement of Islamic Economics, Postgraduate Program, Universitas Islam Negeri KH \\ Ahmad Shiddiq Jember, Jl. Mataram No. 1 Karang Miuwo Mangli Kec. Kaliwates Kabupaten \\ Jember 68136, Indonesia \\ ${ }^{2}$ Departement of Islamic Economics, Faculty of Islamic Economics and Business, Institut Agama \\ Islam Syarifuddin, Jl. Pondok Pesantren Kiai Syarifuddin Lumajang 67358, Indonesia
}

\begin{abstract}
The halal product industry continues to grow and has a big influence on the global market. In fact, Indonesia is determined to make the country's halal product industry more competitive in the world halal market. To anticipate this global market competition, Indonesia as a Muslim majority country must be able to take the advantage of this enormous opportunity. The role of the network in developing halal products to the global market was when marketing its products. PT. Mitratani could not be separated from relationships with business partners. Each business partner had a role to play. Also, PT. Mitratani could not separate the use of information technology and media as a means to expand marketing to the global market.

To create an edge in competition, PT. Mitratani focused on customer and consumer needs. The most important thing was to build trust in business partners. PT. Mitratani's advantage was in the cultivation of edamame. It was from planting to the use of pesticides and fertilizers, until PT Mitratani farmers did their own crops and carried out quality control on each land. This was done to maintain the quality of edamame. PT. Mitratani also improved the quality of its products by implementing HACCP, SOP and GMP in processing and production. In addition to maintaining the quality of PT, Mitratani had established good relationships with company stakeholders so that loyalty and trusted in the product and the company could continue.
\end{abstract}

Keywords: the halal food, strategy of trade, halal food industry.

Article History:

Received: February 1, 2021; Accepted: March 7, 2021; Published:

April 1, 2021

*Corresponding author: e-mail mmunir67@gmail.com

Paper type: Research paper

Cite this document: Munir, Misbahul, AND Masyhuri, Muhammad. " The Strategy of Trade In The Halal Food Industry In Jember" IQTISHODUNA: Jurnal Ekonomi Islam [Online], Volume 10 Number 1 (April 1, 2021)

Abstrak: Industri produk halal terus tumbuh dan berpengaruh besar terhadap pasar global. Bahkan, Indonesia bertekad untuk membuat industri produk halal tanah air lebih kompetitif di pasar halal dunia. Untuk mengantisipasi persaingan pasar global ini, Indonesia sebagai negara mayoritas Muslim harus mampu memanfaatkan peluang yang sangat besar ini. Peran jaringan dalam mengembangkan produk halal ke pasar global adalah ketika memasarkan produknya. PT. Mitratani tidak lepas dari hubungan dengan mitra bisnis. Setiap mitra bisnis memiliki peran untuk dimainkan. Selain itu, PT. Mitratani tidak dapat memisahkan penggunaan teknologi informasi dan media sebagai sarana untuk memperluas pemasaran ke pasar global.

Untuk menciptakan keunggulan dalam persaingan, PT. Mitratani fokus pada kebutuhan pelanggan dan konsumen. Yang paling penting adalah membangun kepercayaan pada mitra bisnis. Keuntungan PT. 
Mitratani adalah dalam budidaya edamame. Mulai dari penanaman hingga penggunaan pestisida dan pupuk, hingga PT Mitratani petani melakukan tanaman sendiri dan melakukan pengendalian mutu di setiap lahan. Hal ini dilakukan untuk menjaga kualitas edamame. PT. Mitratani juga meningkatkan kualitas produknya dengan menerapkan HACCP, SOP dan GMP dalam pengolahan dan produksi. Selain menjaga kualitas PT, Mitratani telah menjalin hubungan baik dengan stakeholder perusahaan sehingga loyalitas dan kepercayaan terhadap produk dan perusahaan dapat terus berlanjut.

Kata kunci: makanan halal, strategi perdagangan, industri makanan halal

\section{INTRODUCTION}

Investment activities related to the capital market. The capital

\section{Background Of Research}

Islam has guidelines for its followers from all aspects of life, including guidelines for consumption. As Muslim consumers, we must pay attention to the halal legalicy of consuming a product, medicine, cosmetics, and food. Especially in the matter of food, in Islam, food is a measure of all initial assessment reflections that can influence various forms of a person's behavior. ${ }^{1}$ Halal products, especially in the field of food processing, are very important for Indonesian consumers, whose majority of the population are Muslim, so they need to be supported by various government policies so that people can feel safer and more secure in consuming various processed food products.

Today, the members states of Organization of the Islamic Conference (OIC) trigger a new wave of enthusiasm, paying special attention to or needing halal products, halal food and Islamic law. Therefore, halal certified

${ }^{1}$ Thobieb al- Asyar, Bahaya Makanan Haram: Bagi Kesehatan Jasmani dan Kesucian Rohani, (Jakarta: al- Mawardi Prima, 2003), 73-74. products have a huge market opportunity, according to current estimates the marketing value of halal products in the global market exceeds US \$ 600 billion. $^{2}$

The halal product industry continues to grow and has a big influence on the global market. In fact, Indonesia is determined to make the country's halal product industry more competitive in the world halal market. To anticipate this global market competition, Indonesia as a Muslim majority country must be able to take the advantage of this enormous opportunity. ${ }^{3}$

The increasing awareness of the importance of food in the Muslim community in the world has led to an increase in the demand for halal food. Indonesia is one of the largest Muslim population in the world, so it has the potential to encourage the development of the halal food industry.

The halal food processing industry is one of the Indonesian

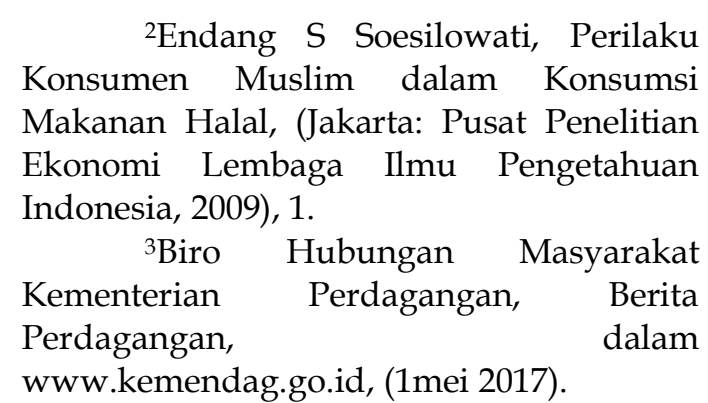

36| Copyright (C 2021, IQTISHODUNA: Jurnal Ekonomi Islam http://ejournal.iaisyarifuddin.ac.id/index.php/iqtishoduna 
industries that has economic potential. The halal food industry is a potential industry that needs to be developed and is called the export industry. According to Dr. Mohd Fuad Mohd Saleh, Dean of the Faculty of Business and Economics, University of Selangor, Malaysia, if you look at the economic situation in Asia, it is hoped that the economy will continue to soar. Also, the potential of the population, especially in Indonesia and Malaysia has the potential to grow halal. If the two countries cooperate in the field of halal food, it will see enormous commercial potential. In particular, consider local and regional large-scale consumption. Regarding income from the food industry, Mohd Fuad Mohd Saleh also assessed that the halal industry opportunity is very large. ${ }^{4}$

Building a product network is a marketing strategy that allows products to be sold successfully. Networking can be defined as the process of establishing relationships and expanding the network of entrepreneurs through a series of long-term relationships between individuals or organizations. ${ }^{5}$

${ }^{4} \mathrm{M}$ Irwan Ariefyanto, Potensi Industri Makanan Halal di Indonesia, dalam

http://www.republika.co.id/berita/pendi dikan/universitas-muhammadiyahjakarta /12/03/23/m1apy7-potensi-industrimakananhalal-di-indonesia. (2 Mei 2017)

${ }^{5}$ Nor Aini Haji Idris, "Bussines Network in Halal Food Industries in Malaysia”, dalam Jurnal Ekonomi Malaysia, Vol 47, No 1 (Malaysia: Faculty of Economy and Manajement, 2013), 88.
Business network is an aspect that must be considered by companies to ensure their products are successfully registered. One of the goals of marketing is to create economic value. Achieving these goals depends on the resources and capabilities of the company include the capital, infrastructure, information technology and company organization. In addition, related intangible resources include a business network consisting of customers, suppliers, workers, competitors and other related business partners. Therefore, the competitiveness and performance of the company depends not only on the company's resources and capabilities, but also on the relationship between the company and domestic and foreign organizations through business networks.

In a global economy, competitiveness is highly dependent on the ability of companies to build business networks with other entities. In today's business environment, business networks play an important role in the development and performance of companies. In the global market, companies are required to carry out quality innovations to meet customer needs. For that, companies need partners who can be relied on to promote their products.

One of the positive impacts of a business network on companies entering the global market is the business network can provide support and information on target 
markets. With business networks in various countries, the company will easily meet the needs of its consumers. Also, the companies can obtain market information related to product sales through business partners in various countries or regions.

East Java Province is the largest soybean granary in Indonesia. It contributes around $42 \%$ of national soybean production. Soybean producers in East Java are scattered in various regions, especially Banyuwangi, Bojonegoro, Pasuruan, Lamongan, Sampang and Jember.

Exported soybeans are a type of edamame which is called a soybean vegetable. Edamame is a vegetable, it must be processed immediately in frozen form and ready to be eaten or frozen to be ready to eat. It means that edamame harvested from rice fields must be processed immediately on the same day, then processed, cooked and frozen until it is ready for export.

Edamame soybeans are Jember's flagship product. Also, the export market for this market is still open, while edamame development is currently only being carried out in Jember Regency. The Japanese market share alone reaches 70,000 tons. Part of it is controlled by China, China 50\%, Taiwan 35\%, and the rest is provided by Thailand, Vietnam and Indonesia. Not to mention other Asian markets, Europe and the United States, so that other areas of East Java and even the entire territory of the country become centers for soybean cultivation, and there are many opportunities for the development of edamame. In addition, the high price of Edamame in the export market is supported by the support of US \$ 1.9 per kilogram or Rp. 20,000 to 220,000 . This is certainly very interesting, because it can generate a lot of foreign exchange, as well as improve the welfare of soybean farmers.

\section{RESEARCH METHODOLOGY}

In this study, researchers used qualitative methods with phenomenological methods. Based on the object selected by the researcher, the research was carried out using field research. As an analytical tool, the researcher used theories from the literature that support the title of this paper and those related to it.

Kirk and Miller define qualitative research as a special tradition in the social sciences, which basically rests on human observation in its fields and aspects. Qualitative research method is often referred to as naturalistic research methods because research is conducted in a natural environment. ${ }^{6}$

\section{DISCUSSION}

\section{Theoretical Framework}

The word of "halal" in the Koran refers to permitted content. 1

\footnotetext{
'Sugiono, Metode Penelitian Pendidikan Pendekatan Kuantitatif, Kualitatif, dan R\&D, Cet. IV, (Bandung: CV. Alfabeta, 2008), 14.
} 
According to al-Jurjānī, the word "alall" comes from a root meaning "open". It means that there is no sanction or any action that can be taken without being bound by law. According to AbūJa'faral-Ṭabārī (224-310 H), ḥalāl means to be released or released Muammad ibn Alial-Shaukani $\bar{i}$ believes that it is legal because he has untied and untied his knot, and there are no restrictions on binding to prevent it. $^{7}$

Halal food is food that can be eaten by Muslims. Islam proves all is well. At the same time, Muslims forbid the consumption of Harran food.

In fact, all food in this world is legal unless there is evidence that is forbidden by the Qur'an or Sunnah. Below is a reinforcing rule on the above statement:

Meaning: The origin of everything is permissible, as long as there is no evidence that forbids it.

The word "tayyib" in Arabic has a good meaning, so that food that is fit for consumption remains fresh and disease free. As a Muslim, one cannot eat whatever one wants. The food we eat must be halālantayyiban which means halal food according to Islamic teachings.

Besides, the opposite of halal is a page which means forbidden. When Muslims are unsure or doubt

${ }^{7}$ Muchtar Ali, “Konsep Makanan Halal Dalam Tinjauan Syariah dan Tanggung Jawab Produk Atas Produsen Industri Halal", Ahkam: Kementerian Agama Republik Indonesia Vol. Xvi, No. 2, (Juli 2016), 292. about halal food or drink, they are classified as "Shubhah".

In essence, every food and drink that derived from plants, vegetables, fruits and animals is legal, except for those that are poisonous and endanger human life. Thus, Allah SWT will not prohibit certain things unless they contain wisdom. Whatever is eaten legally is considered to be good for the human body and life, because whatever we eat will reflect our attitudes and behavior. 8

Clothing and food in the concept of halal can actually be classified into two definitions, namely halal when obtaining food, and halal the nature or ingredients of an item. Obtaining it is halal in food means finding it and getting it right. Not in an unclean way, or in a vain way. Therefore, basically halal food is basically halal, but how to get it through haram, for example the result of theft, corruption and other illegal acts, then automatically the legal status changes to illegal food. 9

On the hand, Another explanation is according to Islamic law. Halal food refers to halal food in nature, the purchase or way of

${ }^{8}$ Emi Normalina Omar dan Harlina Suzana Jaafar, Halal Supply Chain in the Food Industry: A Conceptual Model, IEEI Symposium on Business Engineering and Industrial Application, Langkawi, Malaysia, 385.

${ }^{9}$ Ṭabīb Al-ashar, Bahaya Makanan Haram Bagi Kesehatan Jasmani Dan Rohani, (Jakarta: alMawardi Prima, 2003), 125. 
obtaining halal food and halal food processing. In other words, the food must be absolutely halal. ${ }^{10}$

\section{Halal Food Industry Trade Marketing Strategy}

Before food processing technology developed rapidly as today, the public view of the prohibition of the used of certain products was still very simple. The matter of halal haram or food or drink was only related to whether the product contains pork or alcohol. If the food or drink did not contain these two ingredients, it was automatically considered halal. But now, food processing technology had changed that perception. This was because food production for consummer products no longer only depended on the main ingredients, but also it required other ingredients.

The rapid development of technology and producers were producing food in packaging, it was possible to mix processed food ingredients with materials prohibited by religion. Therefore, the halal of the processed product was questionable. Many of these Harlem materials were used as raw materials, additives or auxiliary materials in various processed products because they were considered more economical.

10Masthu, Makanan Indonesia Dalam Pandangan Islam, (Jakarta: Kantor Menteri Negara Urusan Pangan Republik Indonesia, 1995), 55,106
Market strategy is basically a comprehensive, integrated and integrated plan in the market field, which provides guidance activities for the realization of the company's market objectives. In other hand, a marketing strategy is a set of goals, objectives, policies, and rules, which from time to time indicate the direction of the company's marketing work at each level and its reference. Also, the direction of allocation, especially in response to the company's rapidly changes the environment and conditions. It is still based on the current situation or condition. Also, it is necessary to re-evaluate the marketing strategy that has been determined and implemented. The assessment or evaluation uses an analysis of strength, weakness, opportunity and threat. ${ }^{11}$

Successful product marketing is highly dependent on the promotional techniques used. The one way of promotion is through business relationships. In Nor Aini's research, business networking is the most popular promotional technology and plays an important role in product penetration into domestic and global markets. Entrepreneurs may also use other promotional methods, such as exhibitions, shopping malls, media advertising, the internet, business associations, and word of mouth (a

\footnotetext{
11Sofjan Assauri, Manajemen Pemasaran Dasar, Konsep dan Strategi, ( Jakarta: PT. Raja Grafindo Persada, 2015), hal 169.
} 
form of promotion that recommends the advantages and disadvantages of a product in the form of word of mouth). ${ }^{12}$

Information technology and the internet play an important role as the best promotional media to expand the marketing coverage. Furthermore, e-commerce is considered to be the most economical and fastest way for entrepreneurs to promote their products. Companies are also advised to have their own website as an effective way to prepare for the era of globalization by channeling all relevant information to potential markets. ${ }^{13}$

In addition, there were several types of participants in business networks: social, support, and intercompany partners. Social networks were relationships that exist between many people in one group or between one group and another. Social networks could be formal or informal. Social network refers to informal networks consist the business participants (such as relatives, friends, acquaintances). Social networks are an important means for entrepreneurs to build and develop their businesses. Social networks are considered important for entrepreneurship because they help generate trust and social capital in networks. The support network

\footnotetext{
${ }^{12}$ Lupiyoadi dan Hamdani, Manajemen Pemasaran Jasa, Edisi Kedua, (Jakarta: Penerbit Salemba Empat, 2006), 238.

${ }^{13}$ Nor., Bussines Network in Halal Food Industries in Malaysia., 92
}

consists of supporting institutions such as banks, government agencies and non-governmental organizations. At the same time, a network between corporate partners included the other companies, large or small.

The concept of forming company partners was a concept of strategic alliance. A strategic alliance is a cooperative strategy in which various companies combine their resources. 14 Creating a competitive advantage was the main form of a collaborative strategy. Research in recent decades had shown that strategic alliances can enhance competitiveness. In the globalization era, various forms of partnerships are needed to successfully run a business and survive in the long term.

\section{THE RESULT}

The Strategy of Trade in The Halal Food Industry in Jember (Study on the Implementation of the Edamame Marketing Network for Frozen Food Products PT.

\section{Mitratani 27 Jember)}

Product promotion had a great influence on product sales. Entrepreneurs knew this very well, so they were innovative in promoting their products, so that people paid attention to them. When promoting halal products, entrepreneurs used the "halal label" as a new promotional tool because

\footnotetext{
14Rapma Siahaan, "Perkembangan Jaringan Usaha Menuju Koperasi Berskala Global" Bidang Penelitian Sumberdaya UKMK, Vol. 23, No 1, Oktober, 2013, 47.
} 
the halal label was believed to improve sales performance, especially in the Muslim community. This could be seen clearly from the advertisements circulating on TV which made the halal attribute a new mode in promotional advertising.

The ethical value of the halal label in promotion must be upheld by the company. Companies must maintain public trust in the halal label of their products. The halal label is also a means of communication for producers to convey to consumers, because the products are halal for consumption. When a company includes a halal label, a halal food producer must have a commitment to ensure halal label by implementing three zero concepts, namely zero limit, zero defect, zero risk. ${ }^{15}$

In the globalization era, the development of information technology had become an important means of corporate business. As an information technology company, it recognized market needs.

To promote business development, the companies must use the internet as a promotional medium, it was also recommended that companies have their own website as a business promotion. Prepare yourself for the globalization era and convey

${ }^{15}$ Endang Tjiroresmi dan Diah Setiari Suhodo, Peluang Usaha Produk Halal diPasar Global,, (Jakarta: LIPI Press, 2014), hal 28. relevant information effectively to potential markets. To build relationships with the community, PT. Mitratani carried out several social activities. Those several activities were participated in by many companies and in collaboration with the other companies.

PT. Mitratani also used internet technology to promote its products, providing health information tips, reciped for processed okra and edamame foods. This increased people's desire to consume PT. Mitratani: The use of internet technology as a promotional medium to expand the company's marketing scope played an important role.

For the halal certificate owned by PT Mitratani, the customers in each country had different reactions, some of them did not require a halal label on the packaging, and some required a halal label on it. They knew that MUI is trusted organization that publishes the halal certificates. Also, there were some people who exported to the United States who required a halal halal certificate, or what can be called "koser". Getting the halal certificate must be reviewed by PT. Mitratani. If there was no certificate, the product would not be accepted. The countries that required boarding passes were Israel and several regions in America.

On the other hand, PT. Mitratani also improved product quality by applying HACCP during 
processing and production. The purpose of applying HACCP was to prevent the occurrence of hazards or reduce the risk of product hazards. Then, it guaranteed the quality of food to meet consumer demand. From the preparation of raw materials to the production and distribution of the final product, HACCP acted as a quality control system.

Besides, PT. Mitratani also applied SOP at each stage of processing. There were two employees from the quality control section that supervised each process. Furthermore, PT. Mitratani implemented the GMP in the company to improve the quality of its products.

Indeed, to enter the global market, halal food industry companies must obtain the HHCCP and GMP certification; GMP are production and testing practices that help ensure product quality; companies with HACCP and GMP certifications can easily enter the global market. 16

In facing commercial competition, PT Mitratani did not only maintain and improve the quality of product, but it maintained the price stability. Mitratani used the fluctuation of the US dollar exchange rate as a platform to provide discounts. If the value of the rupiah dropped and the value of the US dollar rose, PT. Mitratani offered discounts for foreign buyers.

\footnotetext{
${ }^{16}$ Nor Aini "Bussines Network in Halal Food Industries, 96.
}

Mitratani was also actively comparing prices with competitors who were also competitors to compare PT. Mitratani competely in the global market. ${ }^{17}$

\section{CONCLUSSION}

The role of the network in developing halal products to the global market was when marketing its products. PT. Mitratani could not be separated from relationships with business partners. Each business partner had a role to play. Also, PT. Mitratani could not separate the use of information technology and media as a means to expand marketing to the global market.

To create an edge in competition, PT. Mitratani focused on customer and consumer needs. The most important thing was to build trust in business partners. PT. Mitratani's advantage was in the cultivation of edamame. It was from planting to the use of pesticides and fertilizers, until PT Mitratani farmers did their own crops and carried out quality control on each land. This was done to maintain the quality of edamame. PT. Mitratani also improved the quality of its products by implementing HACCP, SOP and GMP in processing and production. In addition to maintaining the quality of PT, Mitratani had established good relationships with company stakeholders so that loyalty and

17Sunaryo, Wawancara Jember: Januari 2019. 
trusted in the product and the company could continue.

\section{REFERENCES}

al-Asyar, Thobieb. 2003. Bahaya Makanan Haram: Bagi Kesehatan Jasmani dan Kesucian Rohani, Jakarta: alMawardi Prima.

Ali, Muchtar. 2016. “Konsep Makanan Halal Dalam Tinjauan Syariah dan Tanggung Jawab Produk Atas Produsen Industri Halal", Ahkam: Kementerian Agama Republik Indonesia Vol. Xvi, No. 2, (Juli 2016), 292.

Ariefyanto, M Irwan. 2017. Potensi Industri Makanan Halal di Indonesia, dalam http:/ / www.republika.co.id/b erita/pendidikan/universitasmuhammadiyahjakarta /12/03/23/m1apy7-potensiindustri-makananhalal-diindonesia. (2 Mei 2017)

Assauri, Sofjan. 2015. Manajemen Pemasaran Dasar, Konsep dan Strategi, Jakarta: PT. Raja Grafindo Persada.

Biro Hubungan Masyarakat Kementerian Perdagangan, Berita Perdagangan, dalam www.kemendag.go.id, (1mei 2017).

Emi Normalina Omar dan Harlina Suzana Jaafar, Halal Supply Chain in the Food Industry: A Conceptual Model, IEEI Symposium on Business Engineering and Industrial Application, Langkawi, Malaysia, 385.

Idris, Nor Aini Haji. 2013. "Bussines Network in Halal Food
Industries in Malaysia", dalam Jurnal Ekonomi Malaysia, Vol 47, No 1 (Malaysia: Faculty of Economy and Manajement, 2013), 88.

Idris, Nor Aini Haji. 2013. "Bussines Network in Halal Food Industries in Malaysia", dalam Jurnal Ekonomi Malaysia, Vol 47, No 1, Malaysia: Faculty of Economy and Manajement, 2013, 92.

Lupiyoadi dan Hamdani. 2006. Manajemen Pemasaran Jasa, Edisi Kedua, Jakarta: Penerbit Salemba Empat.

Masthu. 1995. Makanan Indonesia Dalam Pandangan Islam, Jakarta: Kantor Menteri Negara Urusan Pangan Republik Indonesia.

Moleong, Lexy J. 2006. Metodologi Penelitian Kualitatif, Bandung: PT Remaja Rosdakarya.

Siahaan, Rapma. 2013. "Perkembangan Jaringan Usaha Menuju Koperasi Berskala Global" Bidang Penelitian Sumberdaya UKMK, Vol. 23, No 1, Oktober, 2013

Soesilowati, Endang S. 2009. Perilaku

Konsumen Muslim dalam

Konsumsi Makanan Halal, Jakarta: Pusat Penelitian Ekonomi Lembaga Ilmu Pengetahuan Indonesia.

Sugiono, 2008. Metode Penelitian Pendidikan Pendekatan Kuantitatif, Kualitatif, dan R\&D, Cet. IV, (Bandung: CV. Alfabeta.

Suhodo, Endang Tjiroresmi dan Diah Setiari. 2014. Peluang Usaha Produk Halal diPasar Global, Jakarta: LIPI Press. 